\title{
Matrine Treatment Triggers Apoptosis in Colon Cancer Cells
}

\author{
C. CHANG AND JUAN LIU1*
}

Departments of Gastroenterology, Huangshi Central Hospital, Affiliated Hospital of Hubei Polytechnic University, ${ }^{1}$ Public Health, Huangshi Central Hospital, Affiliated Hospital of Hubei Polytechnic University, China

\section{Chang and Liu: Matrine Triggers Apoptosis in Colon Cancer Cells}

\begin{abstract}
The aim of the present study was to investigate the role of matrine, a natural alkaloid from Sophora flavescens with antiproliferative and proapoptotic activities, in human colon cancer using in vitro studies. Caco-2 cell line was treated with increasing doses $(2.0$ and $32 \mathrm{mg} / \mathrm{ml})$ of matrine for $24 \mathrm{~h}$. The MTT assay was used to measure abnormal cell multiplication, while flow cytometry was applied to determine the degree of apoptosis and cell growth. Western blot analysis was also used to detect the expression of various proteins. The results indicated that matrine blocked Caco- 2 cell division in a dose-dependent and time-dependent manner. Matrine triggered apoptosis and blocked mitosis by altering the protein expression levels of B-cell lymphoma-2, B-cell lymphoma-2-associated $X$ protein, cytochrome c, caspase-9 and caspase- 3 . In conclusion, matrine is found to interfere with the proliferation of colon cancer cells in vitro by triggering apoptosis through enhancing the expression of $X$ protein, caspase- 3 and caspase- 9 , as well as suppressing B-cell lymphoma-2 expression. Therefore, matrine is a potential natural compound that could be used in colon cancer treatment..
\end{abstract}

Key words: Matrine, colon cancer Caco-2 cells, antiproliferative

Colon cancer is one of the leading malignancies worldwide, with a high incidence and mortality rate in China ${ }^{[1,2]}$. Studies have suggested an increase in colon cancer incidence in adults aged $<50 \mathrm{y}^{[3]}$. Surgery remains the important curative therapy for colon cancer ${ }^{[4]}$; however, the outcome is not always favourable. Although $70 \%$ of all colorectal cancers are resectable, $50 \%$ of all newly diagnosed patients ultimately develop metastasis. Numerous patients also require adjuvant chemotherapy ${ }^{[5,6]}$, however, this is associated with side effects. Natural products are biologically active with an acceptable safety profile in animal models and thus show promise as therapeutic alternatives for treating colon cancer and hepatoma ${ }^{[7,8]}$.

Sophora flavescens Ait belongs to the Leguminosae family and is grown in South East Asia and Europe for its root, which is dried and extensively used in traditional Chinese medicine to ameliorate infectious and metabolic diseases ${ }^{[9-13]}$. Matrine, an alkaloid with low toxicity, is purified from the dry root of Sophora flavescens Ait. Matrine, $\mathrm{C}_{15} \mathrm{H}_{24} \mathrm{~N}_{2} \mathrm{O}$ with a molecular weight of 248.36 is shown in fig. 1. Its antitumor activity is not known to be associated with obvious toxicity or side-effects ${ }^{[14-16]}$. Recent studies $^{[17-19]}$ suggested that treatment with matrine interfered with the expansion and/or induction of apoptosis in cervix, stomach, liver, lung and breast cancers and blood malignancies. It also enhanced the differentiation of leukaemia K-562 cells $^{[20]}$.

Furthermore, matrine blocked the proliferation of HeLa cells, inhibited the metastasis of human malignant melanoma A375 cells and interfered with the gastric tumor progression in mice ${ }^{[21-25]}$. However, the effects of matrine on human colon cancer and the underlying mechanisms of its action are largely unknown. Therefore, the present study sought to investigate

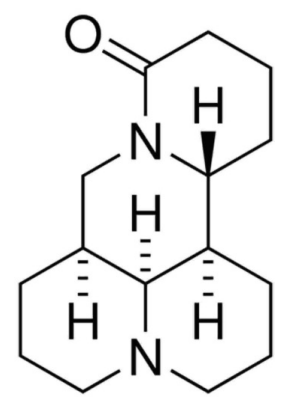

Fig. 1: Chemical structure of matrine $\left(\mathrm{C}_{15} \mathrm{H}_{24} \mathrm{~N}_{2} \mathrm{O}\right)$ 
the role of matrine as an anticancer agent in colon carcinogenesis in vitro.

\section{MATERIALS AND METHODS}

Matrine was obtained from Sigma-Aldrich (USA). The purity of the compound was $>98 \%$, as confirmed using high-performance liquid chromatography. Matrine stock solution $(200 \mathrm{mg} / \mathrm{ml})$ was stored at $-20^{\circ}$ and was freshly diluted using medium prior to use. Fetal bovine serum was purchased from Zhejiang Tianhang Biological Technology Co., Ltd. (China). RPMI 1640 medium was obtained from Keygen Biotechnology Co., Ltd. (China). Sodium dodecyl sulfate (SDS), MTT, L-glutamine and the Annexin V-FITC/propidium iodide (PI) apoptosis detection kit were purchased from Beijing Biosea Biotechnology Co., Ltd. (China). Antibodies specific for B-cell lymphoma-2 (Bcl-2), Bcl-2-associated $\mathrm{X}$ protein (Bax), cytochrome $\mathrm{c}$ and $\beta$-actin were obtained from R\&D Systems Inc, (USA). Anticaspase-3 and anticaspase-9 were purchased from Wuhan Boster Bio-engineering Co., Ltd. (China).

\section{In vitro evaluations:}

The human colon cancer Caco-2 cell line, obtained from the Department of Oncology, Zhongnan Hospital of Wuhan University (Wuhan, China), was incubated in RPMI 1640 medium supplemented with $10 \%$ fetal bovine serum (Gibco; Thermo Fisher Scientific, Inc., USA) under conditions of $5 \% \mathrm{CO}_{2}$ at $37^{\circ}$. Matrine was dissolved dimethyl sulfoxide (DMSO; Sigma-Aldrich, USA) and serially diluted in RPMI 1640 immediately prior to experiments.

\section{MTT assay:}

The cytotoxic activity of matrine was assessed using the MTT assay with different concentrations of the plant extract. The cells were added into 96-well microtitre plates at a density of $5 \times 10^{3}-10^{4}$ cells per well, depending on the cell line. Wells at different concentrations were investigated in triplicate. After incubation at $37^{\circ}$ for $24 \mathrm{~h}$, the medium was substituted with different concentrations of matrine and incubated for an additional 24, 36 and $48 \mathrm{~h}$. The initial concentration of matrine was $1.0 \mathrm{mg} / \mathrm{ml}$ in DMSO, which was serially diluted to prepare 5 final concentrations ranging between 2 and $32 \mathrm{mg} / \mathrm{ml}$. cells were exposed for an additional $4 \mathrm{~h}$ to a humidified atmosphere at $37^{\circ}$, followed by removal of the medium containing MTT. Subsequent to further treatment with DMSO, the absorbance of samples was read at $570 \mathrm{~nm}$. The cell viability was determined in comparison with the negative control containing the solvent without matrine. The percent inhibition of proliferation was determined based on the measured optical density (OD), using the following formula, 1 (average OD of wells containing matrine/average OD of control wells) $\times 100$. All procedures were performed in triplicate.

\section{Mitosis:}

Mitotic analysis was conducted to assess rate of cell death rate as described by Wells ${ }^{[26]}$. Approximately $1 \times 10^{5}$ cells exposed to various concentrations of matrine were mixed with phosphate buffered saline (PBS) at $4^{\circ}$ and centrifuged at $12000 \mathrm{~g}$ for $5 \mathrm{~min}$. The samples were then resuspended in $70 \%$ ethanol and incubated overnight at $4^{\circ}$. The supernatant was discarded and the cells were collected and resuspended in $500 \mu \mathrm{l}$ PI solution (PBS containing $0.2 \%$ Triton X-100, PI at $50 \mu \mathrm{g} / \mathrm{ml}$ and RNase Aat $100 \mu \mathrm{g} / \mathrm{ml}$ ) at room temperature. After $30 \mathrm{~min}$, the status of mitosis was determined using flow cytometry (Sysmex Partec GmbH, Görlitz, Germany) employing Cell Quest software.

\section{Flow cytometry:}

An Annexin V/PI assay was performed using the appropriate kit, according to the manufacturer's instructions. Briefly, cells were plated into 6-well plates and incubated for $24 \mathrm{~h}$ with matrine $(4,8$ and $16 \mathrm{mg} / \mathrm{ml})$. The cells were collected, treated with cold PBS at $4^{\circ}$ and centrifuged at $12000 \mathrm{~g}$. Subsequently, cells were resuspended in $100 \mu \mathrm{l}$ binding buffer containing $2.5 \mu \mathrm{l}$ FITC-conjugated Annexin V and $1 \mu 1100 \mu \mathrm{g} / \mathrm{ml} \mathrm{PI}$ at room temperature.

\section{Cytochrome c release:}

Western blot analysis was performed to determine the level of cytochrome c released into the cytosol. Briefly, the cells were harvested after the ice-cold PBS treatment. The mitochondria and cytosol were separated by sonicating the cells in a buffer containing $10 \mathrm{mM}$ Tris- $\mathrm{HCl}$ (pH 7.5), $10 \mathrm{mM} \mathrm{NaCl}, 175 \mathrm{mM}$ sucrose and $12.5 \mathrm{mM}$ disodium edetate (EDTA). Subsequently, the cell extract was centrifuged at $1000 \mathrm{~g}$ for $10 \mathrm{~min}$ to pellet the nuclei. The supernatant obtained was then centrifuged at $18000 \mathrm{~g}$ for $30 \mathrm{~min}$ to yield the cytosolic fraction from the supernatant and the mitochondrial pellet as previously described. The protein content was measured in the 2 fractions using Bradford's method. Equal amounts of protein were separated by $15 \%$ sodium dodecyl sulfate-polyacrylamide gel electrophoresis (SDS-PAGE) and electro transferred to a polyvinylidene difluoride membrane. The membrane 
was then incubated in $5 \%$ non-fat milk in Tris-buffered saline-Tween 20 [TBST; containing $50 \mathrm{mM}$ Tris, $150 \mathrm{mM} \mathrm{NaCl}$ (pH 7.6) with $0.1 \%$ Tween 20] for $2 \mathrm{~h}$, followed by overnight incubation with the primary antibody separately. The membranes were extensively washed with TBST prior to incubation for $2 \mathrm{~h}$ with the secondary antibody. After repeated washing with TBST, the immune complexes were detected using enhanced chemiluminescence.

\section{Western blot analysis:}

Western blot analysis was performed to determine the protein levels of caspase-3, caspase-9, Bcl-2 and Bax, as previously described ${ }^{[27]}$. Briefly, Caco-2 cells were exposed to different levels of matrine (4, 8 and $16 \mathrm{mg} / \mathrm{ml}$ ) for $24 \mathrm{~h}$, followed by lysis and denaturation. A bicinchoninic acid assay system (Beyotime Institute of Biotechnology) with BSA as a standard was used to estimate the total protein content of the cell extracts. Equal quantities ( $80 \mu \mathrm{g}$ protein per lane) of total proteins were resolved by SDS-PAGE (12\% gels) under reducing conditions. After electrophoretically transferring the proteins to nitrocellulose membranes, a $5 \%$ skimmed milk was used to block the membranes. Anticaspases-3, anticaspase-9, antiBcl-2, antiBax and anti $\beta$-actin primary antibodies were added to the membranes and incubated at $4^{\circ}$ overnight. A goat antirabbit/antimouse secondary antibody conjugated with horseradish peroxidase (1:5000; Abcam, USA) was subsequently added. Immunoblotting of the membranes with $\beta$-actin antibodies after separating previous primary antibodies was conducted. The immunoreactive bands were analyzed using densitometry (Molecular Dynamics, USA).

\section{Statistical analysis:}

All values are presented as the mean \pm standard deviation. Data were analyzed with the Student's t-test, using SPSS version 13.0 program (SPSS, Inc., USA). A $\mathrm{P}$-value of $<0.05$ was considered to indicate statistically significant differences in the results.

\section{RESULTS AND DISCUSSION}

The MTT assay was used to assess the antiproliferative activity of matrine on Caco- 2 cells. Cells were treated with increasing doses of matrine $(2-32 \mathrm{mg} / \mathrm{ml})$ for 24,36 and $48 \mathrm{~h}$. The results indicated that matrine significantly interfered with the proliferation of Caco-2 cells, with an increasing effect observed upon treatment with increasing matrine doses and longer treatment duration ( $\mathrm{P}<0.05$ fig. 2).

To investigate the role of matrine on mitotic progression, cells were cultured at specific doses of matrine $(0,4$, 8 and $16 \mathrm{mg} / \mathrm{ml}$ ), followed by flow cytometric analysis. As shown in fig. 3, increasing doses of matrine significantly increased the cell population in the $\mathrm{G}_{0} / \mathrm{G}_{1}$ stage and reduced the population in the $\mathrm{G}_{2} / \mathrm{M}$ stage. This result suggested that matrine arrested Caco- 2 cells at $\mathrm{G}_{0} / \mathrm{G}_{1}$ phase, resulting in depletion of cells at $\mathrm{S}$ and $\mathrm{G}_{2}-\mathrm{M}$ stages.

Changes in the cell membrane during early apoptosis result in the extracellular translocation of

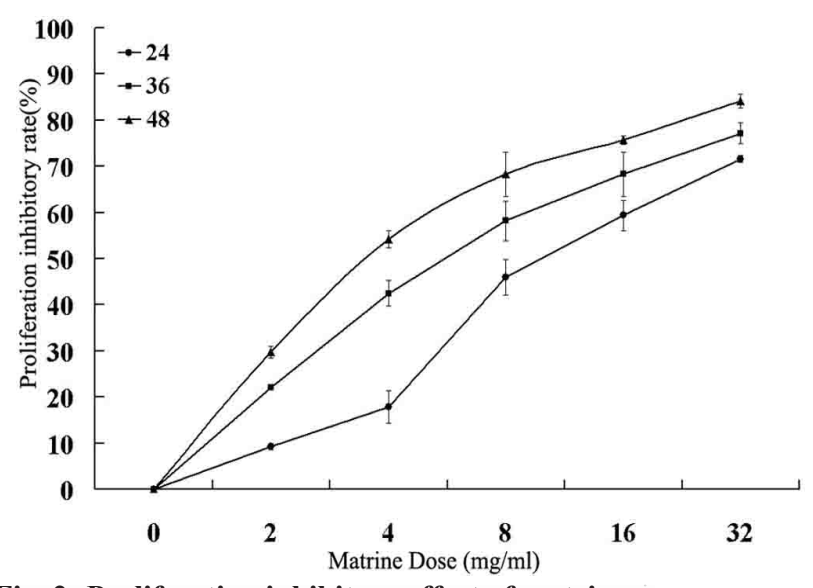

Fig. 2: Proliferation inhibitory effect of matrine
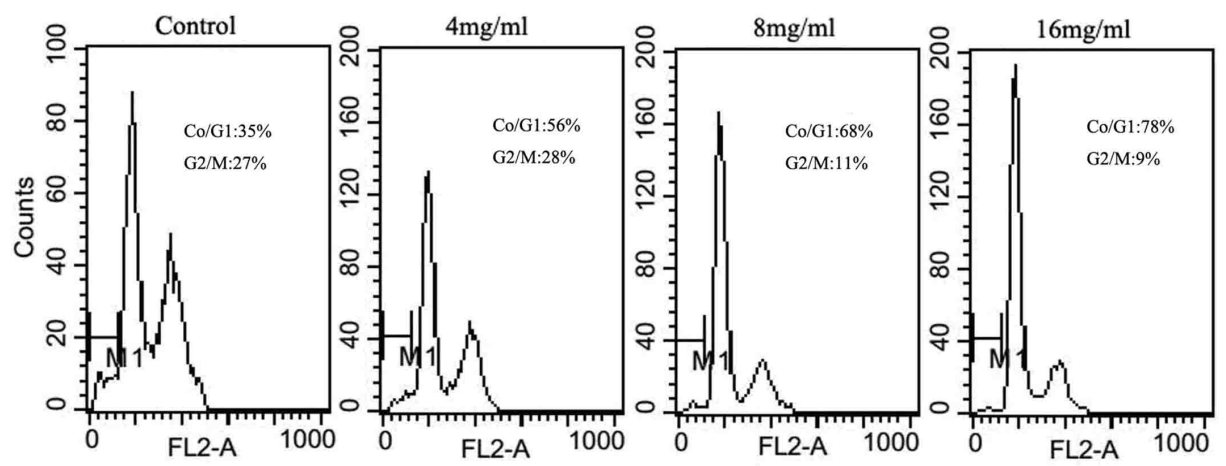

Fig. 3: Cell cycle analysis

Representative DNA fluorescence histograms of PI stained cells. Caco-2 cells were untreated or treated with 4, 8, $6 \mathrm{mg} / \mathrm{ml} \mathrm{matrine,}$ with proportions of $35,56,68$ and $78 \%$ in $G_{0} / G_{1}$, respectively, as assessed by flow cytometry. 
phosphatidylserine. The binding of Annexin $\mathrm{V}$ to phosphatidylserine demonstrates the feasibility of using FITC-conjugated Annexin V to identify apoptotic cells $^{[28,29]}$. Thus, Annexin-V-FITC/PI dual staining was used to detect apoptosis of Caco-2 cells in the present study. Histochemical analysis using PI was used to separate the initial stages of apoptosis from necrosis. The proportion of cells at different stages, including viable, dead or apoptotic phases, was tested in 10000 events collected with a FACScan flow cytometer. The results are illustrated in fig. 4. The living cells were identified in the bottom left quadrant (absence of Annexin V-FITC and PI staining). Cells in the early stage apoptosis were found in the bottom right quadrant (positive for Annexin V-FITC). Delayed apoptosis was characterized by the presence of membrane and nuclear blebbing and cells at this stage were found in the top right quadrant (double staining for Annexin V-FITC and PI). As shown in fig. 4, an increase in early and late stage apoptosis was observed with increasing daily dosage of matrine $(4,8$ and $16 \mathrm{mg} / \mathrm{ml})$. Furthermore, the proportion of delayed apoptotic cells was higher than that of early apoptotic cells.

Apoptotic stimuli triggered the mitochondrial release of cytochrome $\mathrm{c}$ into the cytosol. Along with apoptotic protease activating factor-1, cytochrome $\mathrm{c}$ induces apoptosome formation and activates caspase- 9 and other downstream caspases in a cascade effect. It is evident that matrine is causing apoptosis by initiating the initiator capases-3, progressing the cell death by stimulating caspases-9 continuing the apoptotic activity. Western blot analysis in the current study revealed an increased cytochrome c content in the cytoplasm, depending on the dose of matrine administered, and a concomitant decrease in mitochondrial cytochrome c fraction (fig. 5). The role of matrine on Caco-2 cell proliferation was also investigated using the Western blot analysis to determine the levels of apoptosis-associated proteins. The results indicated that at doses ranging between 4 to $16 \mathrm{mg} / \mathrm{ml}$, matrine abrogated Bcl-2 expression and enhanced Bax levels, resulting in a reduced Bcl-2/Bax ratio (fig. 5). Previous studies ${ }^{[30,31]}$ have demonstrated that Bcl-2 and its potent inhibitor Bax served a critical role in regulating the cellular expansion and apoptosis. Upregulated Bcl-2 increases cell survival by interfering with apoptosis, whereas elevated expression of Bax accelerates cell death. Therefore, the antiproliferative activity of matrine in Caco-2 cells might be mediated by triggering apoptosis and mitotic arrest and by decreasing the $\mathrm{Bcl}-2 / \mathrm{Bax}$ ratio.

Caspases are cysteine proteases that mediate the lethal phase of apoptosis. Matrine was found to enhance the generation of activated caspases- 9 and -3 from their precursors, procaspases- 9 and -3 , respectively (fig. 6). The levels of proteolytically activated caspase- 9 plateaued at a matrine dose of $16 \mathrm{mg} / \mathrm{ml}$, whereas the $17 \mathrm{kDa}$ active caspase- 3 was identified even after $24 \mathrm{~h}$. Advances in neoadjuvant chemotherapy over the past decaderesultedinenhanced survivalprospectsforpatients with colon cancer ${ }^{[32,33]}$. However, chemoresistance is a major challenge, warranting development of innovative therapeutic approaches targeting the malignant behaviour of colon cancer cells for improved prognosis. Matrine is a naturally occurring compound extracted from plants of the family Leguminosae. Plant extracts, particularly matrine infusions, are renowned for efficacy in several diseases and health conditions. Matrine is a safe and effective Chinese medicinal preparation, indicated for inflammatory conditions even in children. Ophthalmological and histological analyses have confirmed the safety of low-dose matrine, when administered to the eyes of rabbits ${ }^{[34-37]}$.
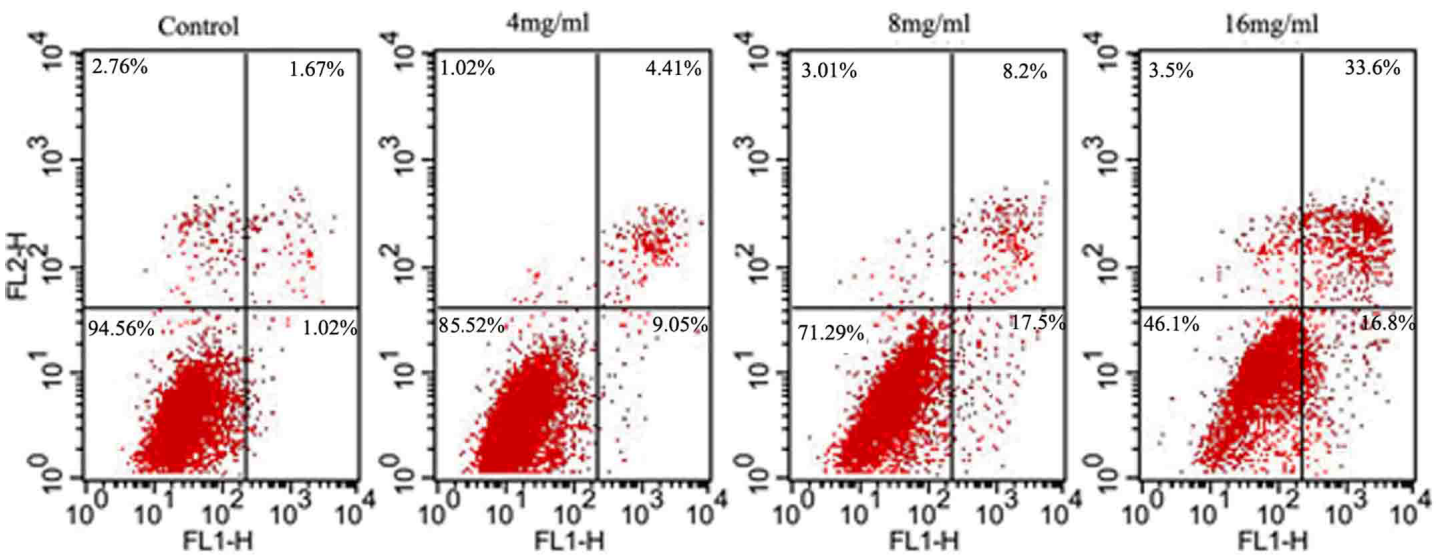

Fig. 4: Apoptosis of Caco-2 cells induced by matrine

Caco-2 cells were treated with or without matrine $(4,8$ and $16 \mathrm{mg} / \mathrm{ml})$ for $24 \mathrm{~h}$ followed by annexin V/PI staining and flow cytometric analysis 


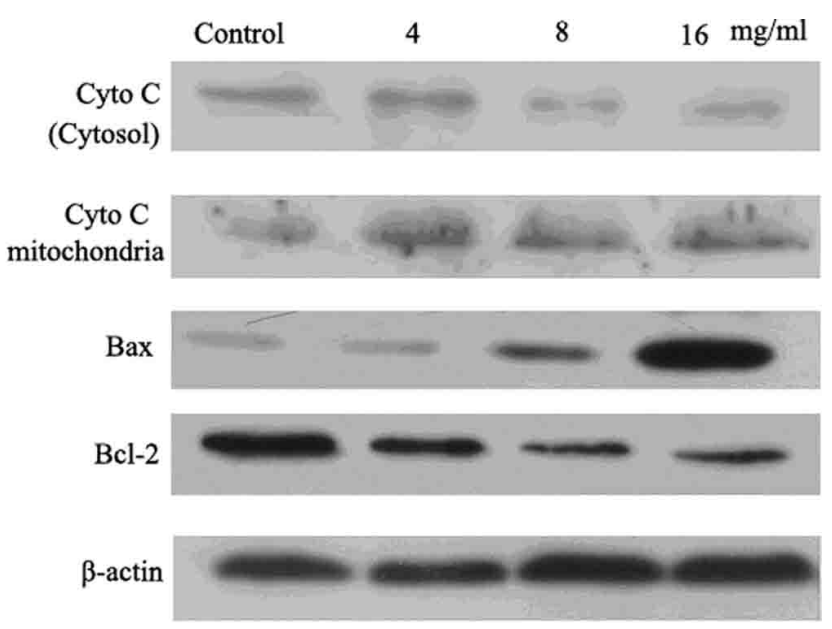

Fig. 5: Effect of matrine on the expression of cytochrome C, Bax and $\mathrm{Bcl}-2$ proteins in $\mathrm{Caco}-2$ cells

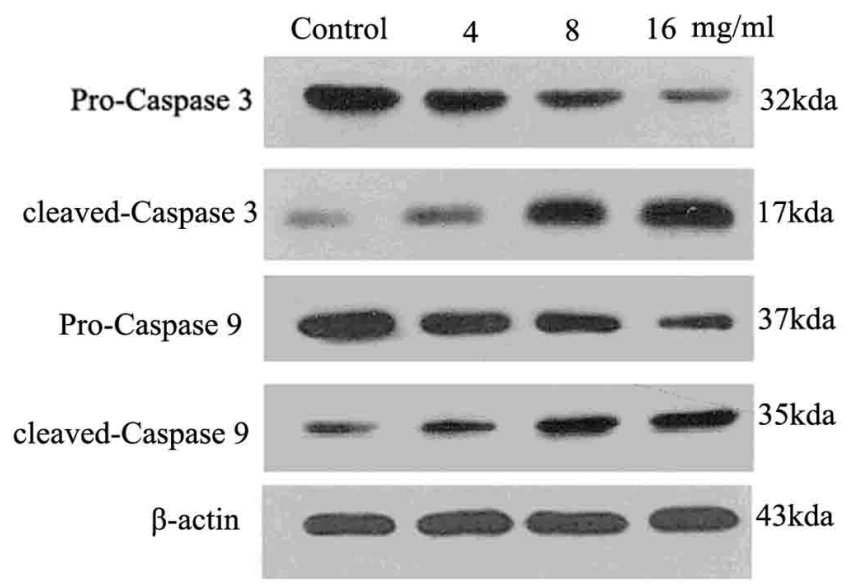

Fig. 6: The expression of caspase-3 and -9 in matrine-treated Caco-2 cells

In the present study, the role of matrine treatment in colon cancer was investigated. The results highlighted the pathophysiology of cancer chemoprevention and chemotherapy. In addition, the anticancer effects of matrine were established in vitro on a colon cancer cell line. As shown by the MTT assay, the growth of the Caco- 2 cells was blocked in a dose-dependent manner, upon exposure to $2-32 \mathrm{mg} / \mathrm{ml}$ matrine. Flow cytometry analysis revealed growth arrest of Caco-2 cells at the $\mathrm{G}_{0} / \mathrm{G}_{1}$ phase followed by depletion of cells in the $\mathrm{S}$ and $\mathrm{G}_{2}-\mathrm{M}$ stages.

Apoptosis mediates not only normal physiology, but also pathophysiology of several diseases and health conditions. Imbalance in apoptosis and proliferation results in tumor development and progression ${ }^{[38-40]}$. Combination anticancer therapies block tumor cell expansion and induce apoptosis. In the current study, the proapoptotic properties of matrine were initially investigated to determine the mechanisms underlying its anticancer effects. Matrine treatment increased the proportion of cells in apoptosis in vitro when compared with the baseline value $(\mathrm{P}<0.05)$. The $\mathrm{Bcl}-2$ group of proteins, including antiapoptotic $\mathrm{Bcl}-2$ and proapoptotic Bax among other members, regulate cellular growth and expansion, pluripotency and apoptosis ${ }^{[39-43]}$. Bcl-2 prevents the secretion of cytochrome $\mathrm{c}$ without disrupting the outer mitochondrial membrane. By contrast, Bax promotes the cytochrome $\mathrm{c}$ release ${ }^{[44-46]}$. In the present study, matrine treatment downregulated Bcl-2 and upregulated Bax, thereby increasing the permeability of the mitochondrial membrane. Immunoblotting revealed that matrine interfered with the proliferation of colon cancer cells in vitro by modulating the expression levels of Bax and Bcl-2.

Caspases mediate the lethal phase of apoptosis. The extrinsic and intrinsic signalling pathways are induced by caspases- 8 and -9 , respectively. Procaspase- 8 is cleaved by mitochondrial protein clusters. Furthermore, caspase- 3 is implicated in apoptosis as a key enzyme ${ }^{[47,48]}$ and is known to induce apoptosis via cleavage of DNA repair molecules, degradation of antiapoptotic proteins, proteolytic modification of extracellular matrix, expression of specific skeletal polypeptides and other molecules. In the present study, matrine treatment was found to induce the mitochondrial release of cytocrome c and eventually increased caspase- 3 activity. Caspase- 3 is expressed as a $35-\mathrm{kDa}$ inactive precursor (procaspase-3), which is activated to a $17-\mathrm{kDa}$ enzyme ${ }^{[49,50]}$. Apoptotic Caco-2 cells exhibited increased levels of activated caspase-3 following exposure to matrine at a dose range of 4-16 $\mathrm{mg} / \mathrm{ml}$.

In conclusion, the results of the present study revealed that matrine prevented the progression of human colon cancer cells in vitro. Matrine induced apoptosis in colon cancer cells by lowering the Bcl-2/Bax ratio, and increased the activation of caspases-3 and -9 . Therefore, matrine may be useful in human colon cancer treatment or adjuvant therapy.

\section{Conflict of interest:}

The authors report no conflicts of interest in this work.

\section{Acknowledgements}

the present study was supported by the Hubei Provincial Natural Scientific Foundation of China (NO.

2013CFC061).

\section{REFERENCES}

1. Guo M, Dou J. Advances and perspectives of colorectal cancer stem cell vaccine. Biomed Pharmacother 2015;76:107-20. 
2. Chen W, Zheng R, Zhang S. Cancer incidence and mortality in China,2013. Cancer Lett 2017;401:63-71.

3. Mármol I, Sánchez-de-Diego C, Pradilla Dieste A, Cerrada E, Rodriguez Yoldi MJ. Colorectal Carcinoma: A General Overview and Future Perspectives in Colorectal Cancer. Int $\mathrm{J}$ Mol Sci 2017;18:197.

4. Plummer JM, Williams N, Leake PA, Ferron-Boothe D, MeeksAitken N, Mitchell DI, et al. Surgical quality in colorectal cancer. Ann Med Surg 2015;5:52-6.

5. Siegel R, Naishadham D, Jemal A. Cancer statistics, 2012. CA Cancer J Clin 2012;62:10-29.

6. Siegel R, DeSantis C, Virgo K, Stein K, Mariotto A, Smith T, et al. Cancer treatment and survivorship statistics, 2012. CA Cancer J Clin, 2012, 62: 220-41.

7. Cragg GM, Newman DJ. Natural products: a continuing source of novel drug leads. Biochim Biophys Acta 2013;1830:367095.

8. Sanders ME, Guarner F, Guerrant R. An update on the use and investigation of probiotics in health and disease. Gut 2013;62:787-96.

9. Yang N, Liang B, Srivastava K, Zeng J, Zhan J, Brown L, et al. The Sophora flavescens flavonoid compound trifolirhizin inhibits acetylcholine induced airway smooth muscle contraction. Phytochemistry 2013:95:259-67.

10. Choi BM, Oh GS, Lee JW, Mok JY, Kim DK, Jeong SI, et al. Prenylated chalcone from Sophora flavescens suppresses Th2 chemokine expression induced by cytokines via heme oxygenase-1 in human keratinocytes. Arch Pharm Res 2010;33:753-60.

11. Kim H, Lee MR, Lee GS, An WG, Cho SI. Effect of Sophora flavescens Aiton extract on degranulation of mast cells and contact dermatitis induced by dinitrofluorobenzene in mice. J Ethnopharmacol 2012;142:253-8.

12. Wang W, You RL, Qin WJ, Hai LN, Fang MJ, Huang GH, et al. Anti-tumor activities of active ingredients in compound Kushen Injection. Acta Pharmacol Sin 2015;36:676-9.

13. Lu S, Xiao X, Cheng M. Matrine inhibits IL-1 $\beta$-induced expression of matrix metalloproteinases by suppressing the activation of MAPK and NF- $\kappa \mathrm{B}$ in human chondrocytes in vitro. Int J Clin Exp Pathol 2015;8:4764-72.

14. Biaoxue R, Shuxia M, Wenlong G, Shuanying Y. Thoracic perfusion of matrine as an adjuvant treatment improves the control of the malignant pleural effusions. World J Surg Oncol 2015;13:329.

15. Rong B, Zhao C, Gao W, Yang S. Matrine promotes the efficacy and safety of platinum-based doublet chemotherapy for advanced non-small cell lung cancer. Int J Clin Exp Med 2015;8:14701-17.

16. Niu H, Zhang Y, Wu B, Zhang Y, Jiang H, He P. Matrine induces the apoptosis of lung cancer cells through downregulation of inhibitor of apoptosis proteins and the Akt signaling pathway. Oncol Rep 2014;32:1087-93.

17. Li H, Xie S, Liu X, Wu H, Lin X, Gu J, et al. Matrine alters microRNA expression profiles in SGC-7901 human gastric cancer cells. Oncol Rep 2014;32:2118-26 .

18. Xie SB, He XX, Yao SK. Matrine-induced autophagy regulated by 553 through AMP-activated protein kinase in human hepatoma cells. Int J Oncol 2015;47: 517-26.

19. Wang W, Cai Y, Zhang G, Liu Y, Sui H, Park K, et al. Sophoridine-loaded PLGA microspheres for lung targeting: preparation, in vitro, and in vivo evaluation. Drug Deliv 2016;23:3674-80.

20. Zhang LP, Jiang JK, Tam JW, Zhang Y, Liu XS, Xu XR, et al.
Effects of Matrine on proliferation and differentiation in K-562 cells. Leuk Res 2001;25:793-800.

21. Zhang S, Cheng B, Li H, Xu W, Zhai B, Pan S, et al. Matrine inhibits proliferation and induces apoptosis of human colon cancer LoVo cells by inactivating Akt pathway. Mol Biol Rep 2014;41:2101-8.

22. Guo L, Xue TY, Xu W, Gao JZ. Matrine promotes $\mathrm{G}_{0} / \mathrm{G}_{1}$ arrest and down-regulates cyclin D1 expression in human rhabdomyosarcoma cells. Panminerva Med 2013;55:291-6.

23. Zhang J, Li Y, Chen X, Liu T, Chen Y, He W, et al. Autophagy is involved in anticancer effects of matrine on SGC-7901 human gastric cancer cells. Oncol Rep 2011;26:115-24.

24. Yu HB, Zhang HF, Li DY, Zhang X, Xue HZ, Zhao SH. Matrine inhibits matrix metalloproteinase- 9 expression and invasion of human hepatocellular carcinoma cells. J Asian Nat Prod Res 2011;13:242-50.

25. Li H, Tan G, Jiang X, Qiao H, Pan S, Jiang H, et al. Therapeutic effects of matrine on primary and metastatic breast cancer. Am J Chin Med 2010;38:1115-30.

26. Wells CE, Bhaskara S, Stengel KR, Zhao Y, Sirbu B, Chagot $\mathrm{B}$, et al. Inhibition of histone deacetylase 3 causes replication stress in cutaneous T cell lymphoma. PLoS One 2013;8:e68915.

27. Dumitru CA, Gholaman H, Trellakis S, Bruderek K, Dominas $\mathrm{N}, \mathrm{Gu} \mathrm{X}$, et al. Tumor-derived macrophage migration inhibitory factor modulates the biology of head and neck cancer cells via neutrophil activation. Int J Cancer 2011;129:859-69.

28. Wu W, Wei N, Jiang CN, Cui S, Yuan J. Effects of sufentanil on human gastric cancer cell line SGC-7901 in vitro. Cent Eur J Immunol 2014;39:299-305.

29. Guo JR, Chen QQ, Lam CW, Zhang W. Effects of karanjin on cell cycle arrest and apoptosis in human A549, $\mathrm{HepG}_{2}$ and HL60 cancer cells. Biol Res 2015;48:40.

30. Yao C, Cao X, Fu Z, Tian J, Dong W, Xu J, et al. Boschniakia Rossica Polysaccharide Triggers Laryngeal Carcinoma Cell Apoptosis by Regulating Expression of Bcl-2, Caspase-3, and P53. Med Sci Monit 2017;23:2059-64.

31. Song Y, Cao W, Zhu X, Qiu Z, Yang X, Liu J, et al. F10, a novel hydatidiform mole-associated gene, inhibits the paclitaxel sensitivity of A549 lung cancer cells by downregulating BAX and caspase-3. Oncol Lett 2017;13:2563-8.

32. Bergquist JR, Thiels CA, Spindler BA, Shubert CR, Hayman $\mathrm{AV}$, Kelley SR, et al. Benefit of Postresection Adjuvant Chemotherapy for Stage III Colon Cancer in Octogenarians: Analysis of the National Cancer Database. Dis Colon Rectum 2016;59:1142-9.

33. Philip CA, Pelissier A, Bonneau C, Hequet D, Rouzier R, Pouget N. Impact of Neoadjuvant Chemotherapy on the Rate of Bowel Resection in Advanced Epithelial Ovarian Cancer. Anticancer Res 2016;36:4865-71.

34. Zhou N, Li J, Li T, Chen G, Zhang Z, Si Z. Matrine induced apoptosis in Hep3B cells via the inhibition of MDM2. Mol Med Rep 2017;15:442-50.

35. An Q, Han C, Zhou Y, Li F, Li D, Zhang X, et al. Matrine induces cell cycle arrest and apoptosis with recovery of the expression of miR-126 in the A549 non-small cell lung cancer cell line. Mol Med Rep 2016;14:4042-8.

36. Peng X, Zhou D, Wang X, Hu Z, Yan Y, Huang J. Matrine Suppresses Proliferation and Invasion of SGC7901 Cells through Inactivation of PI3K/Akt/uPA Pathway. Ann Clin Lab Sci 2016;46:457-62.

37. Zhao B, Li B, Bai S, Shen L, Ren R, Jonas JB, et al. Effects of matrine on proliferation and apoptosis of cultured 
retinoblastoma cells. Graefes Arch Clin Exp Ophthalmol 2012;250:897-90.

38. Chen JC, Su YH, Chiu CF, Chang YW, Yu YH, Tseng CF, et al. Suppression of Dicer increases sensitivity to gefitinib in human lung cancer cells. Ann Surg Oncol Suppl 2014;4:555-63.

39. Sirab N, Robert G, Fasolo V, Descazeaud A, Vacherot F, Taille $\mathrm{AD}$, et al. Lipidosterolic extract of serenoa repens modulates the expression of inflammation related-genes in benign prostatic hyperplasia epithelial and stromal cells. Int J Mol Sci 2013;14:14301-20.

40. Lee JH, Hanaoka M, Kitaguchi Y, Kraskauskas D, Shapiro L, Voelkel NF, et al. Imbalance of apoptosis and cell proliferation contributes to the development and persistence of emphysema. Lung 2012;190:69-82.

41. Liu LH, Zhou YJ, Ding L, Zhang SZ, Sun J, Cao JG. Induction of apoptosis by VB1 in breast cancer cells: the role of reactive oxygen species and $\mathrm{Bcl}-2$ familyproteins. Int $\mathrm{J}$ Mol Med 2014;33:423-30.

42. Lindner AU, Concannon CG, Boukes GJ, Cannon MD, Llambi F, Ryan D, et al. Systems analysis of BCL2 protein family interactions establishes a model to predict responses to chemotherapy. Cancer Res 2013;73:519-28.

43. Goldsmith KC, Gross M, Peirce S, Luyindula D, Liu X, Vu A, et al. Mitochondrial Bcl-2 family dynamics define therapy response and resistance in neuroblastoma. Cancer Res 2012;72:2565-77.

44. Chipuk JE, Moldoveanu T, Llambi F, Parsons MJ, Green DR. The BCL-2 family reunion. Mol Cell 2010;37:299-310.

45. Liang J, Yu Y, Wang B, Lu B, Zhang J, Zhang H, et al. Ginsenoside Rb1 attenuates oxygen-glucose deprivation- induced apoptosis in SH-SY5Y cells via protection of mitochondria and inhibition of AIF and cytochrome $\mathrm{c}$ release. Molecules 2013;18:12777-92.

46. Li Y, Zhang S, Geng JX, Hu XY. Curcumin inhibits human non-small cell lung cancer A549 cell proliferation through regulation of Bcl-2/Bax and cytochrome C. Asian Pac J Cancer Prev 2013;14:4599-602.

47. Yu B, Yue DM, Shu LH, Li NJ, Wang JH. Pseudolaric acid B induces caspase-dependent cell death in human ovarian cancer cells. Oncol Rep 2014;31:849-57.

48. Sun IC, Lee S, Koo H, Kwon IC, Choi K, Ahn CH, et al. Caspase sensitive gold nanoparticle for apoptosis imaging in live cells. Bioconjug Chem 201021:1939-42.

49. Liu MC, Kobeissy F, Zheng W, Zhang Z, Hayes RL, Wang KK. Dual vulnerability of tau to calpains and caspase- 3 proteolysis under neurotoxic and neurodegenerative conditions. ASN Neuro 2011;3:e00051.

50. Martinez JA, Zhang Z, Svetlov SI, Hayes RL, Wang KK, Larner SF. Calpain and caspase processing of caspase- 12 contribute to the ER stress-induced cell death pathway in differentiated PC12 cells. Apoptosis 2010;15:1480-93.

This is an open access article distributed under the terms of the Creative Commons Attribution-NonCommercial-ShareAlike 3.0 License, which allows others to remix, tweak, and build upon the work non-commercially, as long as the author is credited and the new creations are licensed under the identical terms

This article was originally published in a special issue, "Biomedical research applications in Pharmaceutical Sciences"

Indian J Pharm Sci 2020:82(2)Spl issue3;59-65 